\title{
The 'Celtic-Barbarian Assemblage': Archaeology and Cultural Memory in the Fiestas de Astures y Romanos, Astorga, Spain
}

\author{
David González Álvarez
}

Universidad Complutense de Madrid, Spain

Pablo Alonso González

University of Cambridge, UK

The Fiestas de Astures y Romanos (The Festival of Astures and Romans) is a thriving historical re-enactment performed in the town of Astorga, in northwest Spain. The objective of our research has been to explore the complex interactions between politics, the public, and heritage management, and to evaluate their impact upon archaeology as a discipline. We draw on a participant ethnography carried out during the 2011 event. The concept of 'CelticBarbarian Assemblage' enables us to understand how different usages of the pre-Roman past condition identity politics and heritage policies at the local level. Finally, we reflect upon our findings and suggest potential lines of action to tackle what we perceive to be the increasing gap between public and academic archaeology in Spain, whose long-term consequences can be detrimental for the discipline as a whole.

KEYWORDS re-enactment, performance, cultural memory, cultural heritage, archaeology and nationalism

\section{Introduction}

Astorga is a medium-sized town of I2,000 inhabitants located in north-west Spain within the 'autonomous community' of Castilla y León. ${ }^{\mathrm{I}}$ Astorga was founded during the Roman period and was the capital of the Conventus Asturum - one of the Roman provinces of Hispania (Mañanes, I983). During the I970s the town went into economic decline, which led to different social actors in the next decade attempting to transform Astorga into a tourist site with a service-based economy. Accordingly, 
the monumental and heritage aspects of the city were promoted with a specific focus on its Roman past. The authorities implemented a comprehensive system of preventive archaeology and a Roman Museum. Several archaeological sites were preserved and musealized. The first historical re-enactments started in the late I980s, when some people dressed up as Romans during the local festivities. Men and women dressed as Romans also began to act as the representatives of the city in tourism fairs across the nation (Astures y Romanos, n.d. a).

Since the early 2000s, groups of people have started dressing up as 'Astures' during the re-enactments. Astures is a term the Romans used broadly to describe the indigenous communities that inhabited contemporary areas of León and Asturias. ${ }^{2} \mathrm{How}_{-}$ ever, this ethnic labelling does not match the archaeological record, which shows a high degree of internal complexity and variability in the area (González Ruibal, 2OII). The presence of Astures in the celebrations has increased steadily year after year until they equalled the participants portraying the Romans in number. The re-enactment thrived and it became an event in its own right, being held one month before the town's official festivities. The Fiestas de Astures y Romanos (The Festival of Astures and Romans) historical re-enactment was born, reaching its seventh anniversary in 20I (Astures y Romanos, n.d. a; see also Figure I). In a largely festive environment, people stage and perform the events of the Cantabrian Wars (29I9 BC), ${ }^{3}$ in which the Romans defeated and took over the Astures territories (Peralta, 2009; Schulten, I943).

\section{Methodology and objectives}

During the 20II festival the authors carried out an analysis of the event with the following objectives:

- To assess the significance of the event within the local community.

- To analyse the different forms of historical discourse construction, the motivations and organizational strategies deployed by the participants.

- To explore the role of materiality in the construction of discourses about the past in a performative context.

- To investigate how discourses about the past generated in the event influence decision-making at a local level concerning cultural, heritage, and archaeological policies.

We adopted a participant observation approach as members of one of the Astures tribes, the Guigurros (Astures y Romanos, n.d. b). From a twofold anthropological and archaeological perspective, we follow Law (2004) and Smith (2005) in the elaboration of a situated methodology that adapts to the context without a preconceived or rigid scheme. We also assumed Meskell's (2005) proposal to hybridize archaeological and anthropological methods.

Semi-structured and free interviews (King \& Horrocks, 20I0) were employed to gather the necessary data from multiple actors: organizers, re-enactors, visitors, and politicians, among others. During the interviews we raised our research aims and paved the way for the free expression of interviewees' opinions. Moreover, we addressed the discourses produced during the programmed events of the re-enactment, focusing on their narrative and bodily performance in public contexts. The day-to-day life of the 


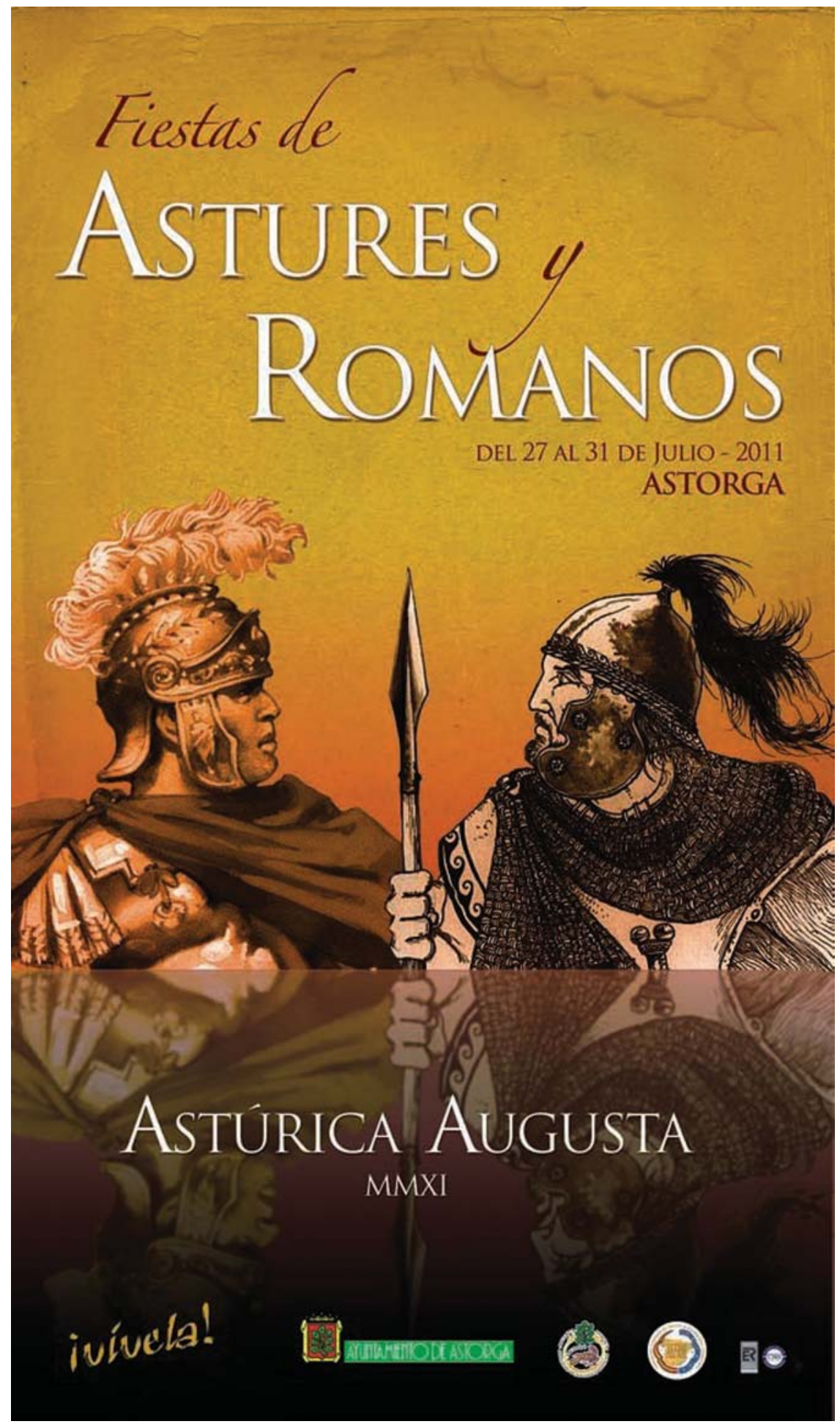

FIGURE 1 Poster of the 2011 edition of the Festival de Astures y Romanos in Astorga (Spain). 
participants was also taken into account, from their informal behaviour to their relation with materiality and visitors. While our primary focus lies in the event's materiality, its media and Internet coverage was also studied.

Overall, our work highlights the significance of the connections and the gaps that exist between the expression and social representation of the past, the public reception and negotiation of meanings, and the institutional heritage management framework. The investigation commits to the principles of a 'public' archaeology (Ascherson, 2000; Merriman, 2004; Schadla-Hall, 1999) that analyses to what extent archaeological knowledge goes beyond academia to permeate the public sphere in Spain. Relatedly, we attempt to uncover the knowledge acquisition pathways of the public and their reinterpretations of academic discourse (Moser, 200I). Although our research reveals inaccuracies between popular representation and archaeological and historical evidence, we do not focus on them as ends in themselves for the sake of 'authenticity', or to carry out an academic critique of popular forms of historical knowledge. Rather, we analyse these inaccuracies and gaps in order to shed light on contemporary issues of memory, identity, and social perceptions of historicity.

We consider the Fiesta de Astures y Romanos as a festive event but also as an exercise of collective memory, where conscious and subconscious decisions are made regarding what is memorialized and what is ignored or forgotten. These choices are fundamental to the way communities (and individuals within those communities) deploy memory 'in the service of providing a usable past' (Wertsch, 2002: 37), whereby the past becomes a resource liable for political utilization in different forms: as a tool to wedge in mnemonic battles over contentious historical pasts (Zerubavel, 2003), or as a representation that legitimizes and naturalizes the present order. These discourses can be subject to analysis because the festival openly represents the 'cultural memory' of the participants and organizers, that is, the collective understanding of the past held by a people in any given social and historical context (Holtorf, 2006).

As in other similar contexts (Bauman \& Sawin, I99I) the power relationships behind our case study become meaningful in the wider cultural context in which they take place. In turn, these influence the history and culture of the public, that is, 'the ways that the past is presented in everyday life, supporting, augmenting, and guiding collective identities that reflect a conscious and unconscious will to remember' (Harvey, 2008: 2I, emphasis in original). However, we do not remain tied to the hermeneutic project of analysing and deconstructing politically charged discourses; instead our materialist account asks how a collective has come to select, recode, and circulate particular objects and meanings and how those are linked with contemporary sociopolitical issues. Following Deleuze (see Protevi, 2006) we consider how specific signs and discourses trigger material processes, rather than just interacting with other signs. Therefore, our research examines the ways local political and economic stakeholders appropriate these representations according to their interests, and how this might influence heritage and archaeological agendas, as well as the roles ascribed to archaeologists.

\section{The Fiestas de Astures y Romanos}

The last two decades have witnessed a drastic growth of historical re-enactments in Spain (Busquets, 2009; Pena, 2004; Rojas Rabaneda, 20II), particularly re-enactments 
of the clash between 'indigenous' and Roman peoples (see Burillo, 2005: 25-27; Jimeno, 2000; Ruiz Zapatero, 2005). Issues of cultural outreach and public interest in the past intersect with the political and economic interests of institutions and local businesses. These events enable the public to actively participate in the representation and performance of the past. As is often the case in the Spanish context, it is difficult and analytically flawed to disentangle cultural motivations from popular celebration. Thus, the re-enactment of the Cantabrian Wars is pervaded with dances, feasts, concerts, nightlife and flirting (see Figure 2). Astorga's tradition of historical re-enactment dates back to the I980s, however, the Fiestas de Astures y Romanos became an autonomous event only in 2005 . Over four days, people from the town construct an Astur village and a Roman camp. They live in their houses with their respective groups, dress up in period clothing, and stage a series of pre-programmed acts: from battles and parades, to ritual ceremonies and a Roman Circus in the bullring.

The growing presence of the indigenous aspects in the event can be related to a shift in the regional political arena. Specifically, the increasing popular support of the regionalist party Unión del Pueblo Leonés (Leonese People's Union) (UPL) and its parallel increasing power-base in the city council. The objective of the party is to transform the Leonese Region into an 'autonomous community' independent from Castile (Díez Llamas, I997) (see Figure 3). Part of its strategy relies on strengthening the Leonese identity through the production of historical discourses highlighting the distinctive traits of the region. The resistance of indigenous peoples to the Roman conquest is employed to exalt the values of those pre-Roman peoples which the UPL considers to be the forefathers of those it represents. In fact, it has been common

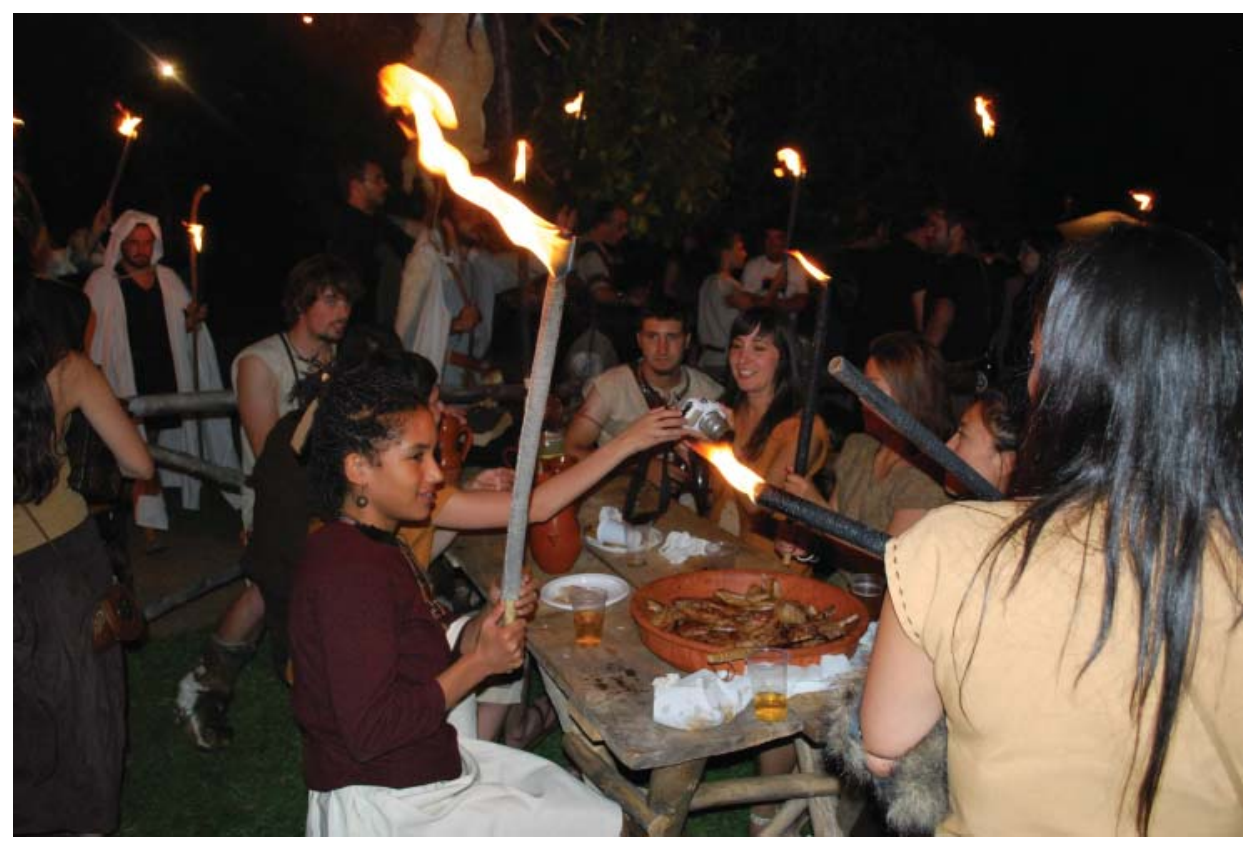

FIGURE 2 Nightlife in the village of the Astures. Participants have dinner the first night of the event. 


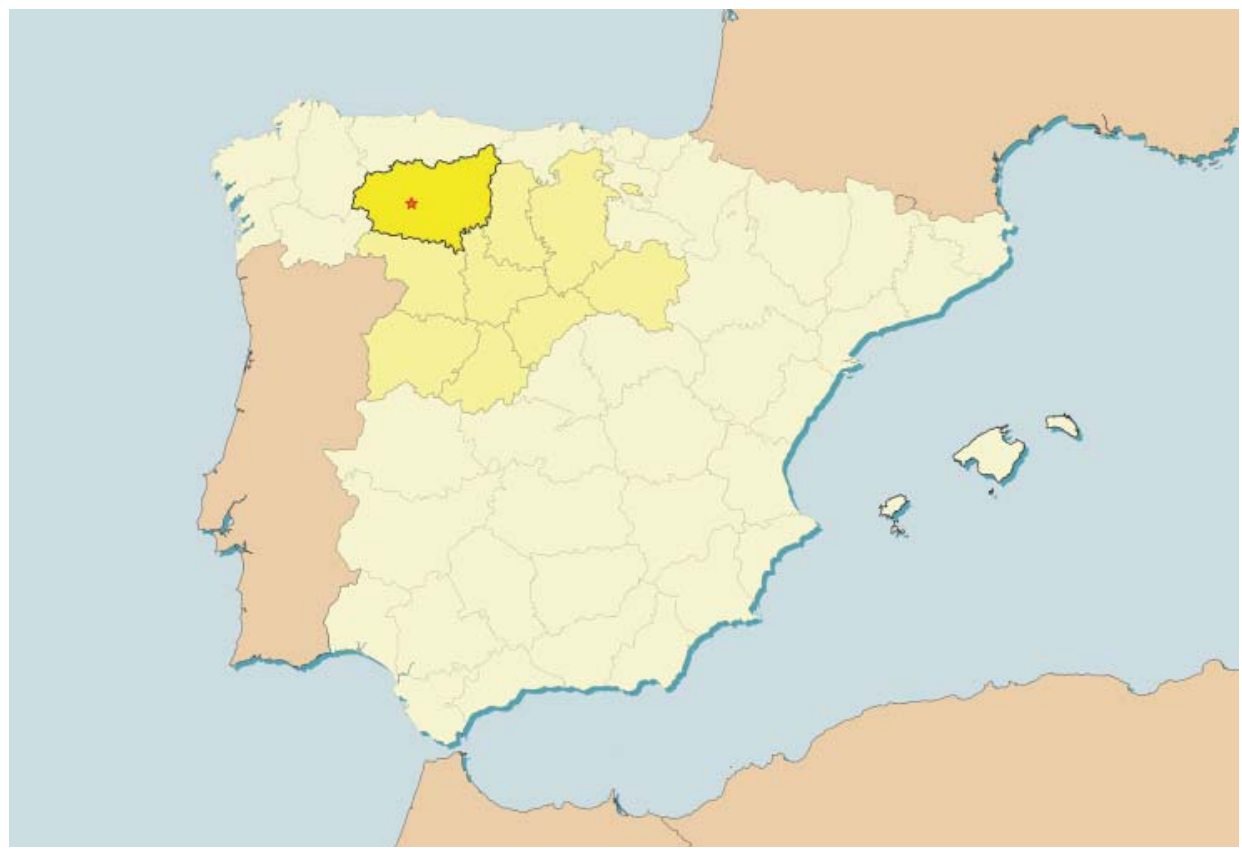

FIGURE 3 Map of Spain highlighting the province of León within the 'autonomous community' of Castilla y León. Astorga is marked with a star.

practice in Spain to mystify the pre-Roman past to underpin nationalist discourses more broadly (Díaz-Andreu, I995). This evinces the relevance of the prospective uses of heritage, as 'all memory is always memory for something' (Geary \& Contreni, I995: I2, italics in original). In particular, regions in the Spanish north-west have relied heavily on 'Celtic' discourses to legitimize regionalist and nationalist claims, serving as a model to the 'Leonesist' movement (Ruiz Zapatero, 2006). Different historical approaches in Asturias (Marín, 2005) and Galicia (Díaz Santana, 2002) highlight the lack of engagement of archaeologists regarding the potentially treacherous political derivations of these self-serving interpretations of the past.

\section{The 2011 festival}

The organization of the re-enactment is provided by the Asociación de Astures y Romanos (Association of Astures and Romans) - which includes many of the participants - and is supported by the city council and local businesses. The association is active throughout the year, with its members attending other re-enactments, and organizing dinners, cultural activities, and excursions. Moreover, it establishes the programme of activities and provides the guidelines for behavioural and material aspects of the event through the 'Regulations' and a 'Commission of Historical Rigour'. The association also allocates a space to each Astur or Roman group to set up their buildings, and it decides what and how to build following a set of more or less pre-established rules and the patterns of more veteran participants. 
The significance of the event is high as nearly a thousand people were actively involved in the 20 I I event, nearly Io per cent of Astorga's population. ${ }^{4}$ Moreover, the local Tourism Office reported that the re-enactment entails an important increase in the number of visitors, along with wide media coverage. In 20II, it was declared an 'Event of Regional Touristic Interest' and was included in the 'Spanish Association of Historical Re-enactments and Events' (AEFRH, n.d.). The Internet is increasingly becoming the fundamental vector for the diffusion of the 'Astur-Roman world' in Astorga, with a webpage (Astures y Romanos, n.d. a), a blog and different profiles on social networks. These sites do not only convey information about the event but also promote its archaeological and heritage elements, thus making a positive outcome for cultural outreach.

Nonetheless, despite these benefits, the event does not connect in any way with Astorga's assorted local heritage assets or its museum: the tourism office does not provide special or extra guided tours for the occasion to complement its standard offering, while the Roman Museum does not hold any activities in connection with the event. This evinces the marked gap between a supposedly 'elite culture' of experts and academics and the 'low popular culture' of the public associated with the festive aspects. This situation is extensive in Spain, where the public deficiency presupposition that considers 'heritage as something communities acquire thanks to museums, heritage sites, school programmes, public archaeology and so on, rather than already being present in individual and collective lives' (Andrews, 2010: 34), is a widespread academic attitude. We believe that the event could be an excellent scenario to connect the 'popular' and 'academic' contexts in real archaeological settings. A contradiction emerges here due to the lack of enhanced and musealized pre-Roman sites that contrasts with the almost exclusive focus on the Roman past in the tourism and heritage agenda of the city. Why this interest in the pre-Roman past if it is not represented or valorized in the local cultural policies? Where are these discourses coming from?

\section{The 'Celtic-Barbarian Assemblage'}

During our fieldwork in Astorga we noticed the existence of specific forms of discursive and material construction of what the Astures should look like. The visual economy of body technologies (Foucault, I977) and material culture - along with the set of practices and discourses deployed during the festival serve to performatively, construct the Astures of the twenty-first century. The Roman side of the event proved to be less interesting because its assemblage of material and discursive elements has been standardized both in Astorga and across Europe long ago, guided by academic scholarship. The Astur phenomenon is far more interesting due to its 'emergent' status and its disconnection from academia. It is an essentially 'popular' movement developing in connection with new socio-political actors and a novel cultural environment. The set of practices and discourses that characterize it coalesce around what we have called the 'Celtic-Barbarian Assemblage' (CBA).

An 'assemblage' can be considered as any number of 'things' gathered into a co-functioning system with some kind of agency, both human and non-human (Latour, 2005), which can bring about varied effects at different levels: productive, performative, behavioural, discursive, and so on. On one hand we find 'actions and 
passions, an intermingling of bodies reacting to one another; on the other hand it is a collective assemblage of enunciation, of acts and statements, of incorporeal transformations attributed to bodies' (Deleuze \& Guattari, I987: 88). Many diverse elements are brought together in the CBA through the connection with other political and socio-economic assemblages. However, the elements drawn from academic knowledge are anecdotal, which again evinces the gap between archaeological scholarship and the public. Contrarily, alternative references are situated at a similar or higher level than scientific archaeology. Among these we can include pseudoarchaeological and historical narratives - mostly related to the sphere of the 'Celts', in vogue throughout Europe - Nordic and Irish mythology, the fictional worlds of J. R. R. Tolkien's Lord of the Rings, films such as Braveheart or Conan the Barbarian, and comics like Astérix (Collis, 2003; James, I999; Ruiz Zapatero, 2010).

Furthermore, our research has shown how this assemblage does not remain tied to the local, but draws from and is reproduced at the regional, national, and European scales. We also witnessed aspects of what we term the CBA at work during our participation in the Guerras Cántabras festival (Los Corrales de Buelna, Cantabria) and the Festival Astur-Romano de La Carisa (Carabanzo, Asturias), which are in a range of $300 \mathrm{~km}$ from Astorga. The 'assemblage' is replicated through processes of mimicry that customize it for local contexts. Consequently, it also presents different degrees of evolution: Los Corrales de Buelna is the older festival; hence Astorga emulates aspects of Los Corrales de Buelna while Carabanzo, the most recent one, draws from both. Moreover, it is replicated in other European contexts where the prehistoric past is not central, being particularly suitable in relation to medieval fairs and markets. Thus, the CBA can be defined as a set of 'templates that organize modes of behaviour and reasoning that have the distinctive capacity for decontextualization and recontextualization, abstractability and movement, across diverse social and cultural situations [...] able to assimilate themselves to new environments, to code heterogeneous contexts and objects' (Collier \& Ong, 2005: II).

Thus we have been able to document the creation of this form 'in the making' and to broadly ascertain its interconnected defining traits:

\section{Otherness}

The identity of the Astures is constructed as a cultural 'other'. In clear dialectical fashion, the Astur identity contrasts with the central or 'triumphant' identity of the Romans. However, this does not imply the acknowledgement of the existence of an alternative viewpoint. Rather, the identity of the Astures is built at different levels through the establishment of sets of contrasting dichotomies with the Romans (see Table I). This confirms Kristian Kristiansen's insights on the Barbarian-Roman opposition across Europe, which suggested that:

the Classical dichotomy between 'Civilisation' and 'Barbarism' has [...] played a major role in shaping the political ideology of European nation-states, thereby also implicitly influencing research objectives and interpretations in archaeology. (I996: I38)

While Rome is seen as a centre of European civilization, the barbarians - equated in our case with the Astures - are regarded 'as the original source of uncorrupted freedom' (Kristiansen, I996: I38); an 'Other' that stands in opposition to Rome. 
TABLE 1

TABLE SHOWING A SET OF IDEAL DICHOTOMIES BETWEEN ROMANS AND ASTURES AT PLAY DURING THE RE-ENACTMENT

\begin{tabular}{ll}
\hline Astures & Romans \\
\hline barbarian & civilized \\
primitive & modern \\
native & foreign \\
natural & artificial \\
organic & forced/regular/tidy \\
durable & perishable \\
peace/harmony & violence \\
spontaneous & predictable \\
dirty & clean \\
round & square \\
irrational & rational \\
\hline
\end{tabular}

\section{Presentism and essentialism}

The past is viewed in similar terms as the present, and thus performed, understood, and judged equally. Participants project contemporary 'common sense' onto the past by conveying to the public a biased and distorted set of ideas and meanings that naturalize present realities. The Astures are presented as embodying a set of preconceived elements that 'fit a scheme', such as dirtiness, incivility, barbarianism, and belligerent attitudes, or love for nature.

\section{Lack of temporal and geographical depth}

Many elements from different prehistoric, historic, and epic worlds are lumped together into the CBA, from Bronze Age petroglyphs to Elvish runes. Time is 'messianic', a simultaneity of past and future in an instantaneous present (cf. Benjamin, I999: 265).

\section{Holism and simplification}

The Roman world is represented as an elite society engaged in leisure activities, while the Astures are represented mostly by warrior elites. Moreover, the latter are conceived as an organic unity where each of the tribes functions as a part of the whole body, performing a specific role: for example, as fishermen, leaders, or shepherds. Some of these characteristics arise from the paradox described by Lowenthal (I996) that the more people attempt to know the past, the more they replace it with a common sense version that resembles their own reality, recreating their object of attention in a perfect and desirable form (see also Haraway, I989).

\section{Material culture in the construction of the CBA}

The CBA emerges, is naturalized, and is reproduced through different 'regimes of signs' (Deleuze, I988). Material culture codifies the assemblage through two fundamental 
vectors: body technologies along with internal and external domestic environments (the vectors are discussed further below). Overall, the Astur village may be characterized by an organic organizational pattern, where material heterogeneity and craftsmanship in the constructions prevails. It conveys an idealized portrait of the Astures as free 'barbarians' living in communion with nature and the supernatural, devoid of any internal conflict. In turn, the Roman camp exhibits a rational and regular spatial ordering, constructive homogeneity, and a limited physical and visual accessibility to the visitor. The materiality of the camp emphasizes Roman culture as a civilizing agent that brings progress, order, and cleanliness.

\section{Body technologies}

The dress of the Astures is made of cloth, leather, and fur. Body paint and make-up complement dress as fundamental markers of the different recreated identities (see Figure 4). Homogeneity prevails within each group. There is no role or gender differentiation: all members in the tribe are warriors, fishermen, farmers, and so on. The archetypal Astur subject is the male warrior, a model assumed by women and children (see Figure 4: C, D). The adoption of a masculine and belligerent role by women contributes to the concealment of the 'maintenance activities' (González Marcén et al., 2008), minimizing the role of women in pre-Roman society and naturalizing contemporary patriarchy (Hernando, 2005).
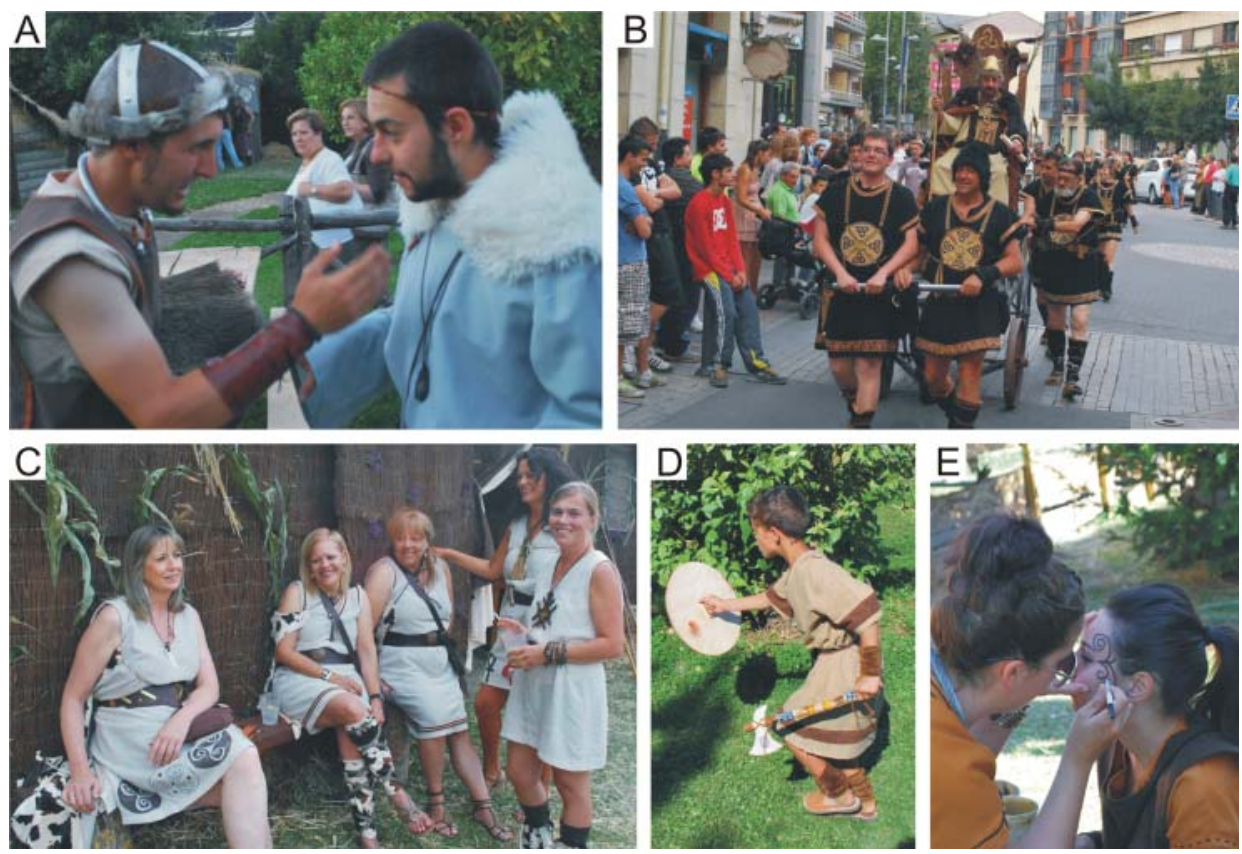

FIGURE 4 The pictures show Astures from different tribes. There are some significant characters with distinctive clothing, such as a druid (A) and 'Sebius', the Astur chief (B). The dressing of women and children imitates the male warrior dress (C, D). Beyond clothing, body painting is an essential body technology (E). 
The Romans dress in robes of coloured cloth, with the exception of some military characters wearing armour and chain mail. Unlike the Astures, heterogeneity prevails among Roman groups: there is a clear separation between genders and professions; for example, there are no warrior women. Clearly, Roman participants employ body technologies to individuate themselves, individuation representing modernity and civilization. Meanwhile, the Astures remain bounded to their collective representations which defy individuation. The fundamental Roman subject is the 'individual', whereas the Astur person is superseded by the 'collective' (i.e. the tribe). In turn, tribes are conceived as parts or a larger organic whole: the 'Astur people', whose socio-political unity is asserted in different events. The roles represented among the Romans exclusively refer to stereotyped aristocracies. This ideal elite representation of the Roman excludes peasants, artisans, or slaves. This overall state of things results from a mixture of the decisions of the organizers and the initiative of the different participant groups.

There are some exceptions to the rule of internal homogeneity in the body technologies among the Astures. Generally, one of two male subjects assume specific roles as warrior leaders or druids, disrupting the apparent horizontality of the tribes. These individuals use different strategies to distinguish themselves such as the accumulation of markers of symbolic status: weapons, jewellery, or valuable clothes or horns, amongst others. For example, the leader of the tribe of the Ambactos and chief of all the Astures, Sebius (see Figure 5), embodies a baroque assemblage of symbolic markers: a golden and horned helmet, metal pendants and bracelets, an antennae dagger in his belt, fur covering his clothes, triskelions printed on his clothes and weapons, and a signa equitum Celtiberic crook similar to those found in eastern-central Iberia some hundreds of kilometres away from Astorga (Lorrio, 20Io). Moreover, these subjects assumed or were endowed with the role of 'experts', the knowledgeable individuals of each group to which their fellow tribe companions referred us to to answer our questions: 'he's the one who knows'. Contrary to the situation described by Crang (I996) where the presence of academics is strongly felt, in our case study participants did not consult academics, whose presence in the re-enactment was limited to a conference on Roman army equipment held in the town's library attended by twenty-two people.

The Astures normally carry hand-made reproductions of weapons. The quintessential weapon is the sword. The presence of spears is low in spite of being the most commonly found in the archaeological record of the area (Marín, 20II). This is only one of the many paradoxes arising in the construction of the Astures through body technologies. Such paradoxes reflect the existing deficit in public knowledge transfer and outreach in Spanish archaeology. At the same time, these paradoxes make sense within the framework of the CBA; presentism and the simplification of historic discourses characteristic of the event derive from the widespread projection of contemporary attitudes onto the past. The Astur identity is thus constructed in a dialectical and retrospective fashion as opposed to the Roman. Consequently, it makes sense that they fight each other with similar weapons - swords. Similarly, regimes of representation tend to converge. Thus, the Astur chieftain, Sebius, has to be seated in equal conditions next to the Roman Caesar to preside over different social acts with an opposing body set of technologies, of course. 


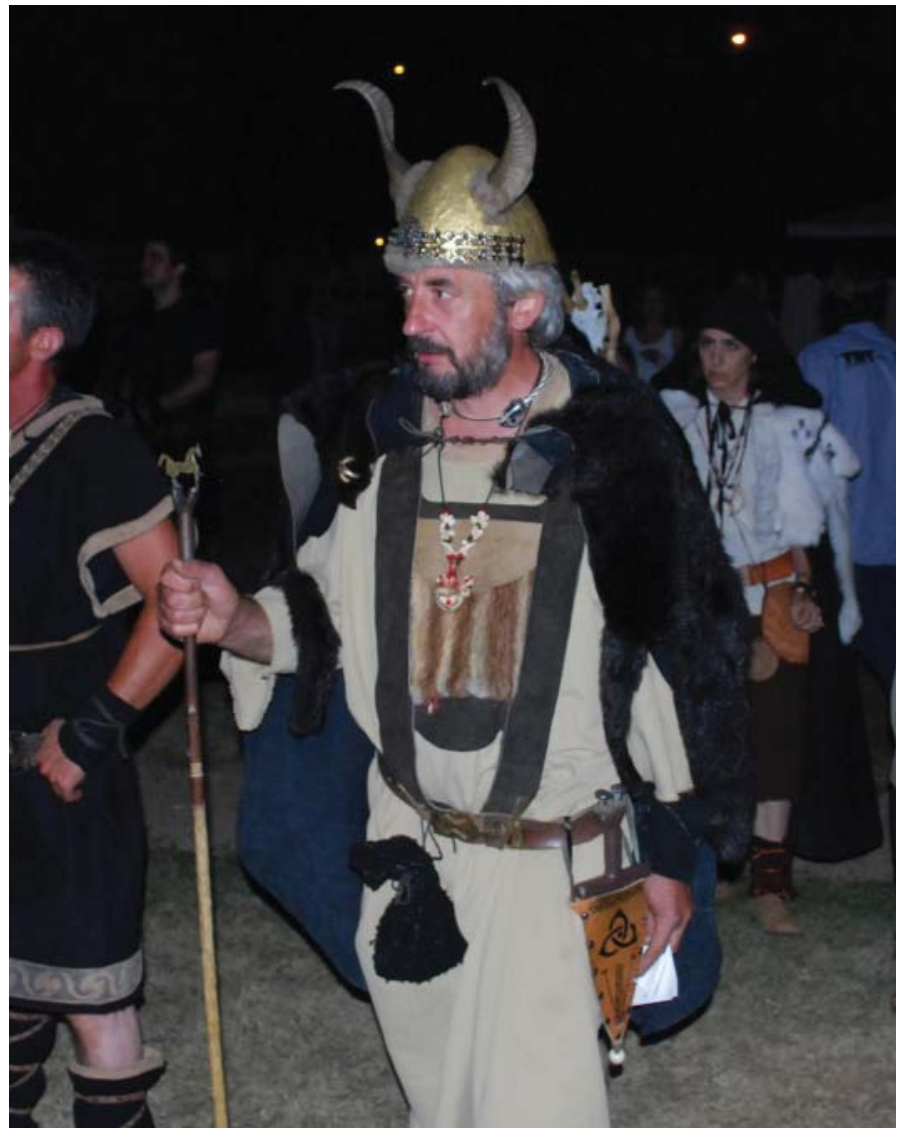

FIGURE 5 'Sebius', chief of the Astures.

An episode of our ethnography encapsulates the pervasive common sense interpretation of the past and the mirroring of the Roman body technologies. While visiting one of the Astur huts, one of the participants was explaining to another member of the tribe the constructive details and materials of the chain mail he was wearing, which resembled the Roman ones. When we asked him about it and how he knew that the Astures used to wear chain mail, he confidently replied, 'there must be some in archaeological sites, I guess'. Disregarding the fact that there is no archaeological evidence of Iron Age chain mails in the area, his attitude revealed the will to imitate Roman models and thus acquire symbolic capital through distinctive material culture.

Despite some guidelines provided by the organizing association, each group has autonomy to shape its dress. This is done intuitively and often through mimicry. Some tribes seek simplicity, while others favour the accumulation of symbolic elements drawing on the vast range of symbolic and material elements that the CBA provides: Elvish runes, Scottish textiles with squared decoration, horned Viking helmets, Celtic triskelions, and so on. Nonetheless, our ethnographic observations revealed that some participants had tailored their dress drawing on information found in museums. Thus, it is clear that a minority of participants were actually interested in cultural issues and strived to follow the models sanctioned by expert knowledge. 
Scholars of public archaeology should intervene at this point to analyse the friction arising between the knowledge acquisition pathways of the public and the reinterpretation and practical implementation of that knowledge during the re-enactment.

\section{Material culture at the domestic spaces}

The spatial distribution of huts in the Astur village develops unsystematic (see Figure 6). These generally exhibit a circular or elliptic plan and use wooden and vegetable materials in roofs and walls (see Figure 7). Meandering pathways between the trees connect the huts and their external fenced areas, where participants spend most time together, drinking, eating, and chatting. The huts erected in the re-enactment follow the model of reconstructions in preserved archaeological sites and of vernacular architecture from the area. In a further example of the disconnect between public perceptions of the past and 'expert' archaeological knowledge, the participants do not rely on the models provided by nearby excavations where Iron Age houses are square in plan (Sánchez-Palencia \& Fernández-Posse, I986-87). From our standpoint, this situation partly derives from the generalized public assumption of the precepts put forward by the culture-historical archaeological paradigm. This paradigm has been broadly brought under the unifying label of 'Castro Culture', the rather complex and multi-cultural world of the Iron Age in north-western Iberia (González Ruibal, 20II). The 'Castro Culture' presents the castros (hillforts) as archetypal representations of the period with rounded houses such as Coaña (Asturias) or Santa Trega (Pontevedra). These narratives are assumed by the public, which tends to adopt simplifying models and discards complex narratives independently of their correspondence with historical reality. Thus, we can see how the construction of the CBA involves a complex interplay of elements in which intuition

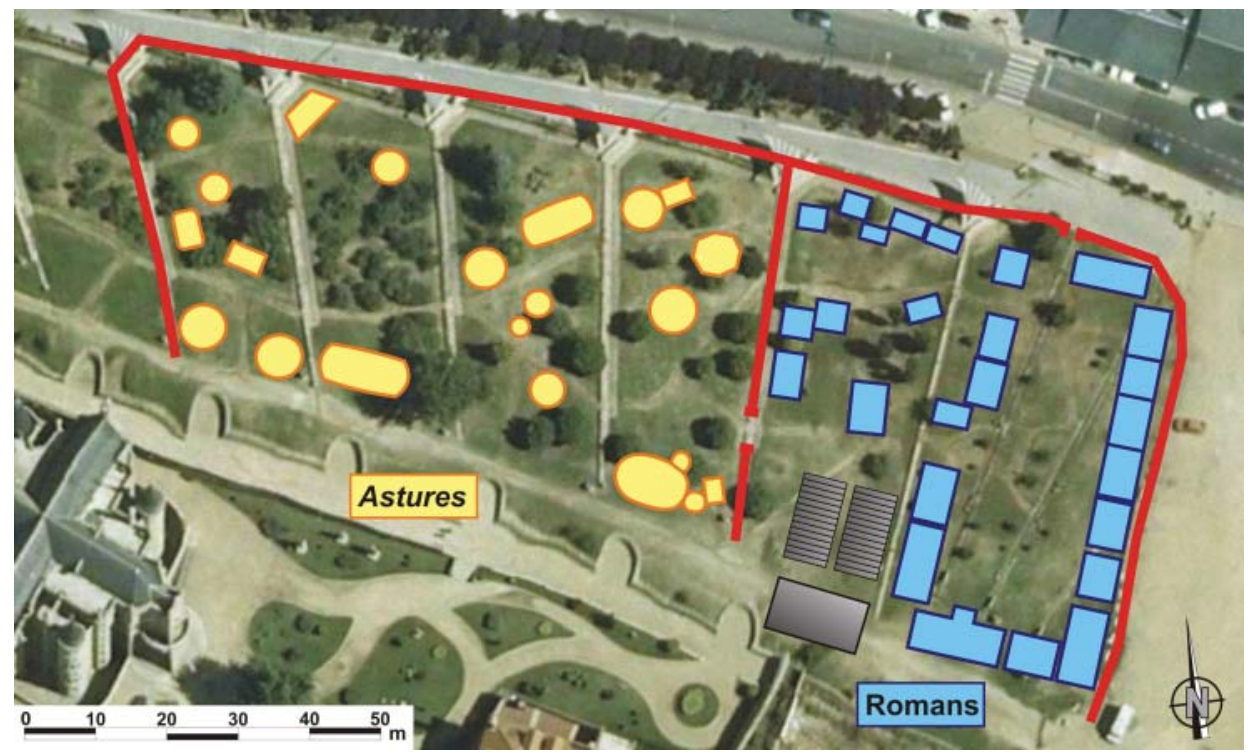

FIGURE 6 Map showing the spatial distribution of the Roman camp and the Astur village. 

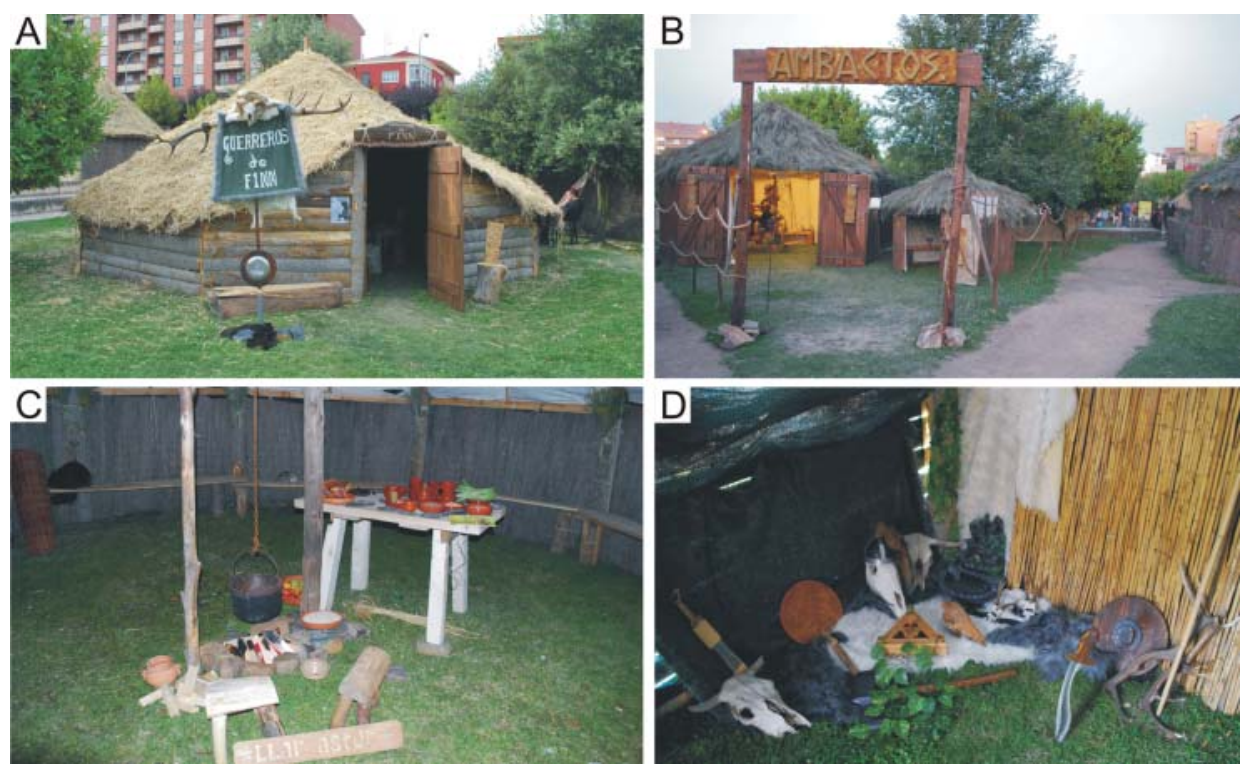

FIGURE 7 Pictures of Astur huts.

and common sense function as mediators transforming and simplifying museum and academic discourses.

The Roman camp represents order and civilization, and is physically and symbolically opposed to the Astur village. It displays square buildings based on modular steel structures covered with canvas (see Figure 8). Roman groups set up these prefabricated structures along an orthogonal organization of the urban grid devoid of trees. This leaves an empty central square that conveys the idea of a symbolic 'public sphere', and functions as such during the re-enactment. The air of rationality is emphasized by the formal homogeneity of Roman tents. Their external display shows fundamentally classic scenes where material reproductions and prints in fabric of columns, capitals, statues, pots, and flowers prevail. The Roman materiality and the structure of the camp are characterized by a set of standardized and homogeneous elements replicated throughout Europe (Appleby, 2005). This leaves little room for the creativity and agency of the participants, in clear contrast with the creativity and craftsmanship proper of the CBA.

The internal areas of the Astur huts offer a stereotypical representation of a building inhabited by the indigenous warriors. Normally, they present multiple objects on display in tune with the core of the CBA. The widespread presence of small shrines stands out (see Figure 7: D). These are used to expose weapons, herbs, animal skulls, horns, and other figurines from contemporary 'New Age' mythologies based on the 'Celtic factoid' (James, I999). Also, the presence of elements from vernacular culture such as wooden preindustrial ploughs is notable. This rhetorical device is part of the 'invention of tradition' (Hobsbawn \& Ranger, I992) and serves to stress the connection between 'our' vernacular ancestors and the pre-Roman 'original' inhabitants of the area (see Figure 9). 

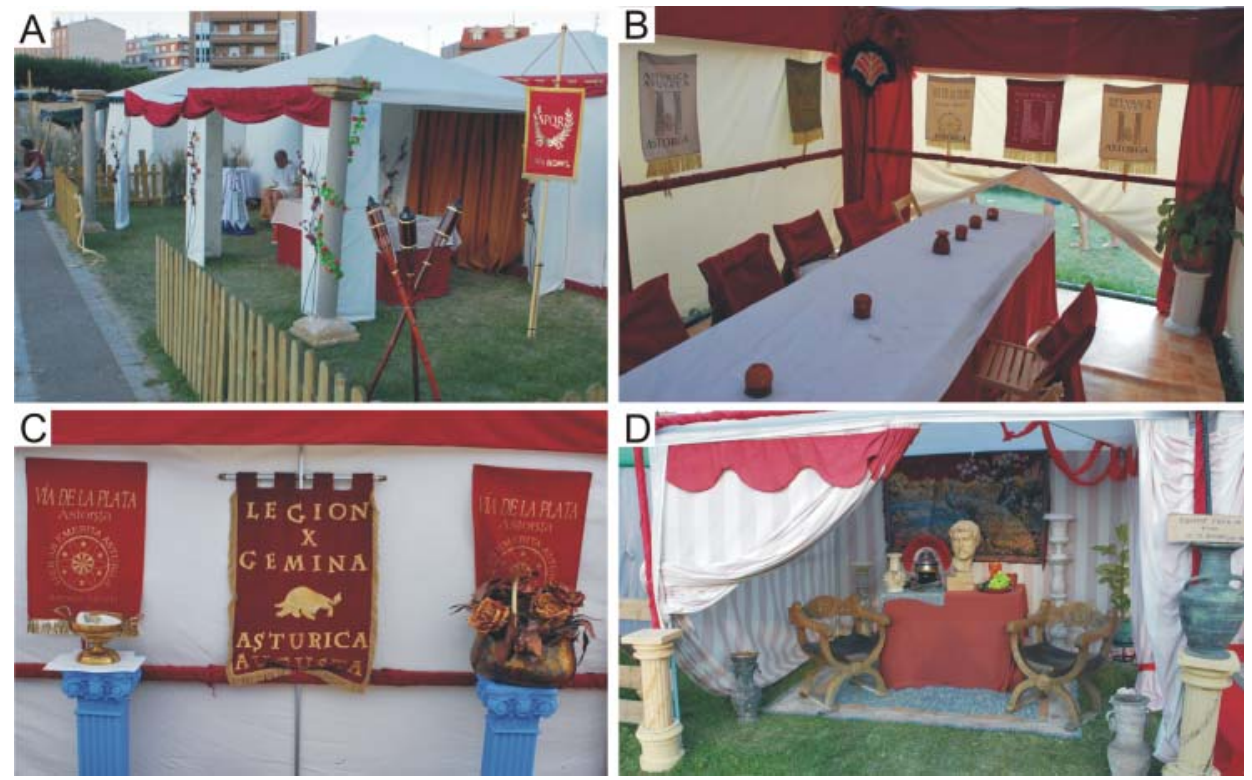

FIGURE 8 Pictures of Roman tents.

Generally, Astures' huts are open and socially permeable, which facilitates the entrance of visitors. Some tribes actively interact with the public, inviting the visitors to join them, and display texts explaining what they term their 'ethnic origins'. The writings of classical authors like Strabo (64 BC-AD 24) - the Classical Greek Geographer - play a fundamental role here, although these are reinterpreted and elaborated with pseudoscientific narrations easy to retrieve online. ${ }^{5}$ The Roman camp presents a significantly lower pedagogic intention. The internal areas of the houses represent halls or aristocratic leisure areas and are rarely open to visitors.

The Asociación de Astures y Romanos favours these practices and sets certain standards of authenticity. Thus, both houses and participants are encouraged to disguise contemporary elements: plastic, sunglasses, clocks, or bags — some Roman groups were fined for utilizing plastic chairs. Meanwhile, other attitudes and elements without any archaeological or historical basis are tolerated: the Astures drink from horns, the Osborne bull ${ }^{6}$ with the Spanish flag in the background is present in some Roman banners, and representations from different periods are lumped together as 'Iron Age elements'. Of course, all this is justified because it fits with the logic of the CBA.

Ultimately, the pronounced differences between the two villages in material terms can be connected with the broader context of heritage and archaeological management in Astorga. While the Roman past has been promoted through the Roman Museum, the Roman Route of the Tourism Office, and some musealized archaeological sites (Ranilla \& Grau, 20II), the pre-Roman past of the municipality has been marginalized. The only attempt to understand and promote the indigenous past of the area coincided with the power of the regionalist party UPL in the city council. Sadly, the ongoing excavation of the Iron Age hill fort of La Mesa since 2006 has not 

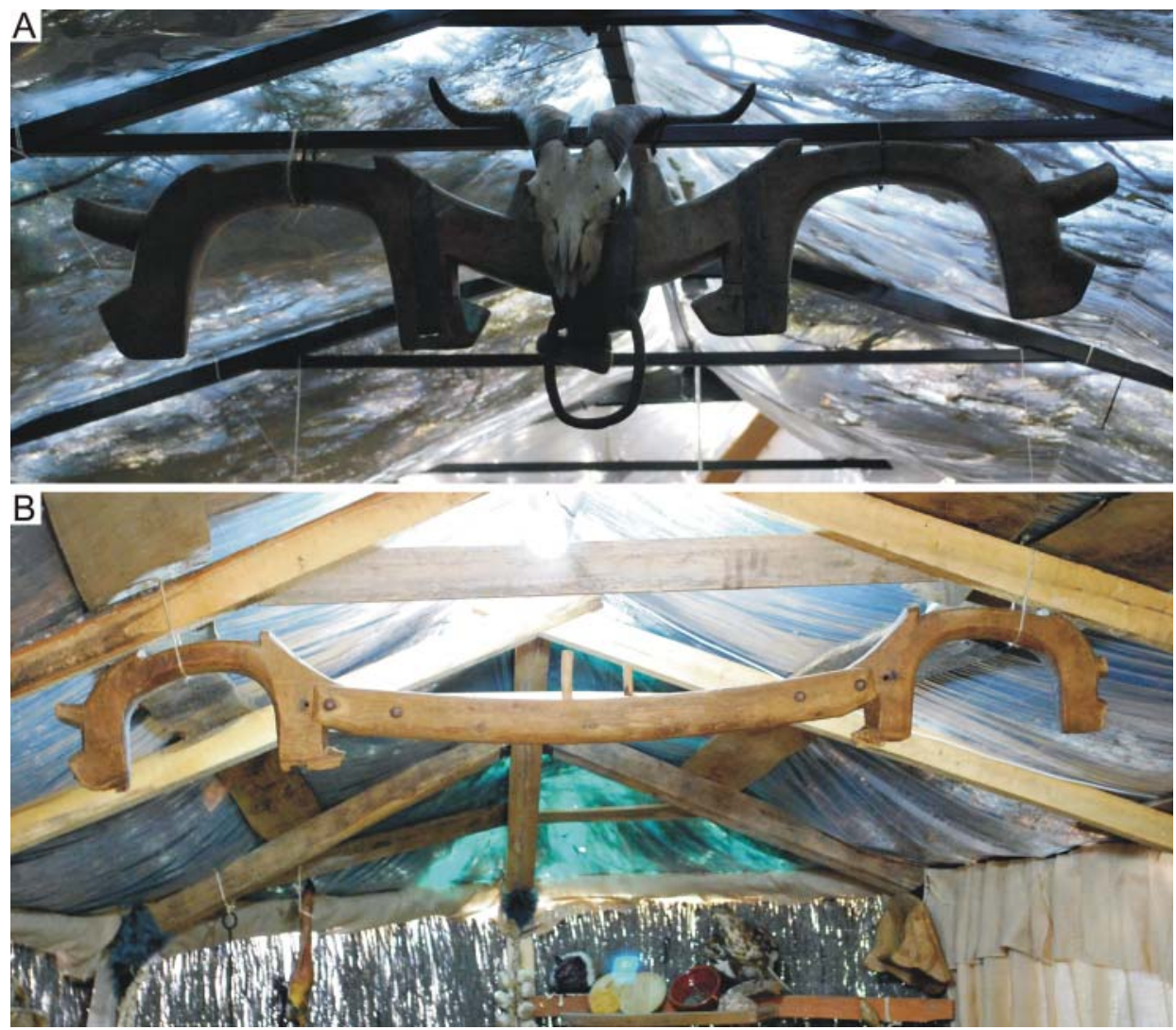

FIGURE 9 Pictures of vernacular yokes on display inside Astur huts.

led to any publication or to projects for its conservation and promotion. From our standpoint, the profusion of amateur museological and pedagogic efforts in the Astur village is intended to fill the gaps produced by local heritage management policies.

\section{Discourse and practice}

During the Fiestas de Astures y Romanos the overall joyful environment contributes to the simplification and stereotyping of the events and protagonists of the Cantabrian Wars (29-I9 BC). The official programme stages the historical narration as conveyed by classic authors such as Florus (c. AD 74-I30), Orosius (c. AD 375-after 4I8) and Cassius Dio (AD I55-235). Similar events such as those in Carabanzo and Los Corrales de Buelna present equivalent narrative structures adapted to the local context. Fundamentally, armed confrontations between indigenous peoples and Romans are staged while a narrator recounts the events (Figure Io: A). The construction of the narration stands halfway between the classic sources and the constitutive traits of the CBA, the latter reinforced by background music from the films Gladiator, 300, Braveheart, and the Lord of the Rings. In a clear melodramatic fashion, the underlying message conveyed is that the Astures are the vanquished heroes. The idea that 

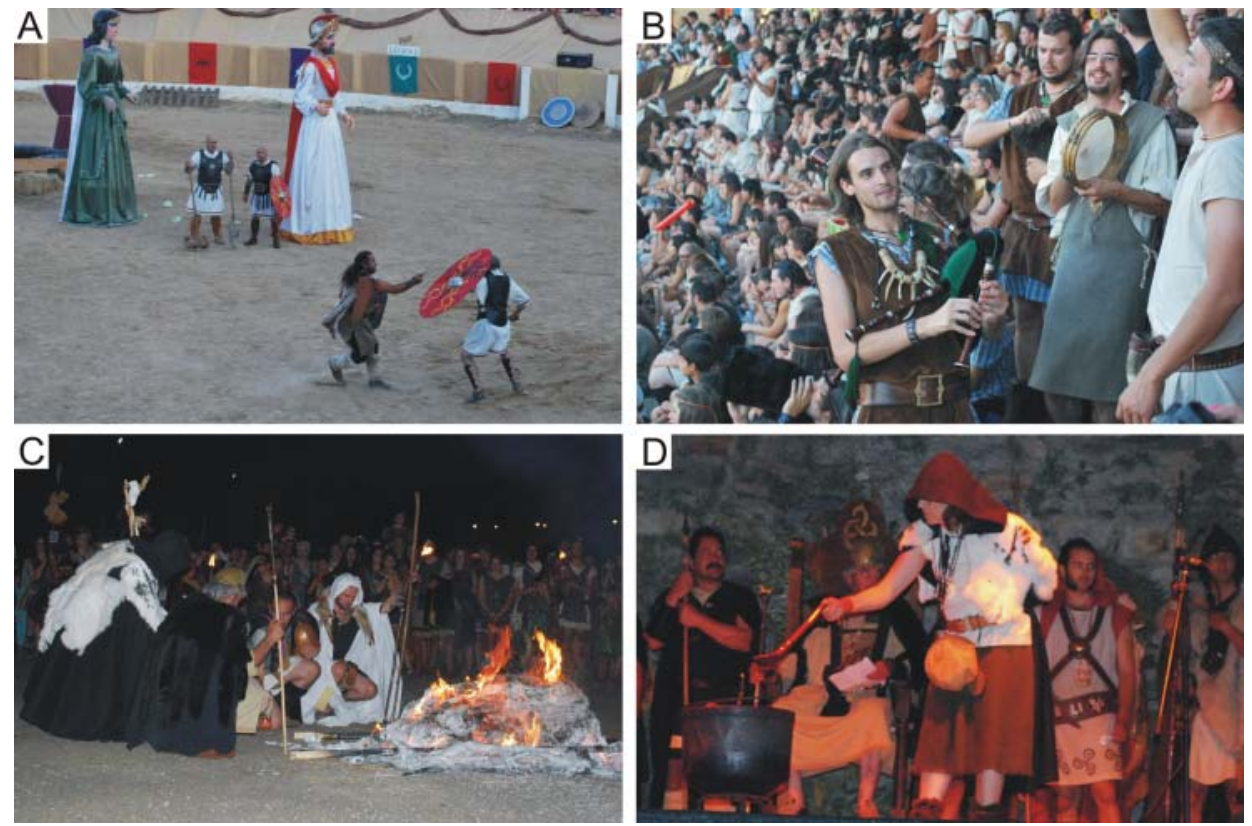

FIGURE 10 The pictures show the Roman Circus (A, B), the incineration of Gausón, an Astur warrior (C), and the performance of a queimada to summon the indigenous Gods (D).

their identity remains 'latent' is highlighted; the Astur soul could not be conquered by the Romans. This connects with the general public and historic-culture ideas prevailing until the I980s in academia affirming that the Astures were not Romanized, or only superficially so (Barbero \& Vigil, I979). This paves the way to the establishment of connections between past identities and vernacular societies, as renowned ethnographers like Caro Baroja (2003: I03) did so eagerly, opening the door to political appropriations of the pre-Roman past. Materially, this is evinced by the previously mentioned display of vernacular tools from preindustrial peasant local communities in the walls of the huts and the use of traditional woollen cloth or pottery from local craftsmen.

Other parallel activities such as parades or ritual ceremonies stand apart from the festival's central activities. The ceremony with the most symbolic content is the 'acclaim of the Astur chieftain', in which the Astures consult their gods and decide to go to war against Rome. Representatives from each tribe pay allegiance to Sebius dressed in their finery and covered with symbolic elements of prestige, characteristic of the CBA. During the act, an Astur female druid invokes the meigas or by preparing a queimada and intoning spells in Galician - a language spoken in the nearby region of Galicia, but not in León ${ }^{7}$ (see Figure Io: D). The re-enactment closes with the incineration of the warrior Gausón ${ }^{8}$ (see Figure Io: C). Incineration has not been documented archaeologically and its performance here can only be understood as an importation from the 'Celtic factoid' (James, I999). Moreover, this prehistoric hero performs heroic deeds with the alleged intention of 'going down in history'. 
These discourses project contemporary social roles and ideas onto the pre-Roman past, thus naturalizing them in the present. Common sense mediates the whole process and filters what is socially acceptable or not, and archaeological narratives must jump through this hoop. In this context, the difficulty of representing the indigenous 'Other' (Hill, I989), or of recognizing 'an-Other-paradigm' (Mignolo, 2007), can be understood. Equally, the naturalization of patriarchy and the representation of the subaltern role of women makes sense in this context: female warriors are such not because the existence of women warriors during the Iron Age is recognized. Rather, it is so because the CBA disregards features that individualize identities, subsuming individuality under a generic conceptual vagueness of the Astur phenomenon. This paves the way for highlighting the harmony of the Astur community, which contrasts to the individuality of the Romans and avoids dealing with problematic questions of gender. A similar situation arises with class. There is an overall lack of representation of productive activities and subjects, both in the martial Astur village and in the aristocratic Roman camp. Thus, 'the Astur people lived in communion with nature and in peace under the designs of their warrior chieftain until the arrival of the Romans', as the narrator states during the acts of the 'War declaration to Rome'.

The multiple symbolic, discursive, and material elements imported from other geographic and symbolic realms and comprised in the CBA, without any correspondence with the archaeological record of the Astures during the Iron Age, have something in common. At their root, they work as socially successful identity markers opposed to 'the Roman'. They represent a vague tradition of the local warrior, rooted in the land and nature, who opposes the 'global' and 'dominant' invader. Ultimately, this 'warrior' embodies the Volkgeist of the local against the foreigner. All these cultural referents, highly evolved in neighbouring regions like Galicia or Asturias (Díaz Santana, 2002; Marín, 2005), are incorporated to the re-enactment in Astorga without any filtering or cultural mediation. As the CBA is still developing here, it becomes possible to analyse how contemporary ideological discourses connect in different forms with the event. In Spain, these discourses normally converge in the construction of regional or national identities in relation with the legitimization process of the new autonomous communities (Marín et al., 20I2).

\section{Knowledge practices, the public, and mediation}

Our study has analysed the strategies of discursive constructions and knowledge transfer emerging in the Fiestas de Astures y Romanos re-enactment. In order to extend our analysis, first, we deem it necessary to define our concept of 'public'. There are always many publics, and different degrees of involvement and motivation among the participants of the festival. The majority of those attending the festive are passive subjects for whom the festive aspect is the ultimate incentive to participate. However, certain people with a high degree of involvement play a fundamental role in the elaboration of materiality, practices, and discourses. We have called them the 'hinge subjects', the 'experts' of each tribe or group. They function as nodal points connecting different sources of information about the past with the reality of the re-enactment, mediating knowledge practices and transforming them. Because they are perceived as the legitimate conveyers of the 'authorised heritage discourse' (Smith, 
2006), they are key in the transmission of the knowledge that pervades the event and which is transmitted to more passive participants and visitors.

Multiple sources of information converge in the creation of these discourses. The participants place great confidence in the classic Roman authors. Those are considered to be reliable sources of information that must be represented as accuracy as possible. Critical academic readings of these sources are ignored. These underscore the "etic's character of the Roman authors and their biased simplifications in the ethnographic description of the Astures, depicted as barbarians who are yet to be civilized. Similarly, the intrinsic political motivations behind the accounts provided by the authors and the lack of correspondence between their narratives and the archaeological record are ignored (Marín \& González Álvarez, 20I I; Salinas, I998).

Archaeology remains in the background as a provider of decontextualized objects and iconographies: all archaeological remains prior to the Roman period are lumped together under a singular and diffuse category. Ultimately, the obscene paradox lies in the fact that narratives affirming the local Astur identity ground their legitimacy in the imperialist and 'foreign' Roman texts, which are accepted uncritically. The nature of the classic sources lends itself to these kinds of misleading uses as their narrative vagueness and geographic imprecision allows participants to rework and elaborate their contents. Thus, passages from Strabo's Geography employed to characterize the Astures could be perfectly suitable for any other barbarian beyond the boundaries of the Roman Empire. In fact, the conceptual vagueness and uncertain ethnic categories employed by Roman authors could be said to be the basis of the pan-Celtic cultural generalizations at the European scale.

Similarly, this general ambiguity facilitates the incorporation of multiple discursive and material elements from different origins that end up forming the core of the CBA. The Internet has become the crucial source and medium for the diffusion of these elements. These pseudoscientific elements are not only created and diffused, but also discussed and talked about endlessly in online forums (see endnote 5). The very nature of the Internet precludes the possibility of having filters that validate the accuracy of certain affirmations and discourses, which take on a life of their own and ultimately, are actualized in the re-enactment.

However, the 'hinge subjects' also draw on information provided by museums and reconstructed archaeological sites in order to develop the materiality and discourses of their respective tribes during the re-enactment. In doing so, 'hinge subjects' introduce 'noise' in their process of mediation, materializing their own constructions deriving from the hybridization of multiple sources of information (Internet, museums, common sense, pseudo-archaeology, and so on). In any case, this is one of the few channels by which academic knowledge reaches the public. For instance, the musealized Iron Age hillfort of El Chano (Peranzanes, León) served some 'hinge subjects' as inspiration for the design of their own houses and dress. Of course, this knowledge undergoes a translation without any cultural mediation or local adaptation, as demonstrated above in the case of the square and round houses. The vague and ambiguous character of the CBA renders these translations possible and justifiable.

In light of these considerations, it makes sense that the chieftain Sebius governs the destinies of all the Astures, unified under his rule. On the contrary, contemporary archaeological debates tend to understand the area as a complex mosaic of hillforts with rather inward-looking attitudes and divided into small-scale ethnic groups 
(González Ruibal, 20II; Marín, 20II). From this standpoint, the large-scale identity label of Astures only arises as a simplified cultural construction derived from the 'etic' standpoint of Roman authors (Marín \& González Álvarez, 20I I; Salinas, I998).

Cornelius Holtorf has argued that 'the perceptions of the many matter as much as, or more than, the factual knowledge of the few' (2005: 8). Therefore, instead of blaming the participants for their reinterpretations and inaccuracies, presupposing their ignorance, we should look at the efforts of our own professional archaeological communities (Andrews, 20I0). The presence of researchers at these sorts of events is very low in Spain. Their absence is also manifest in the environment where the thematic content of the events are produced and discussed (e.g. Wikipedia, blogs, forums, non-academic journals). What are the reasons for the absence of academics? It might be partly due to a fear of the public questioning the power position of the researcher, normally beyond discussion. In addition, academics face the difficulty of transmitting complex meanings, while the simplicity and populist rendering of the past provided by the CBA is easily reworked and consumed by the public. Moreover, the active participation in public events or the production of outreach content does not lead to an increase of the academic capital of the researcher. In Spain, the academic career is assessed by the public agency 'Agencia Nacional de Evaluación de la Calidad y Acreditación' (ANECA), whose research parameters barely consider participation, outreach, and knowledge transfer (ANECA, n.d.). Finally, traditional academic production grounded in historic-culture and positivist schemes is widely available in libraries and the Internet, whereas critical research developed since the I990s is generally not publicly available. This fact is related to the prevailing academic editorial system that increasingly privatizes the outcomes of research (in subscription-based scholarly journals, etc.), independently of whether public or private bodies have funded it.

In light of all this, can archaeology be considered socially useful in Spain? The average citizen does not probably perceive it to be so. In our opinion, this situation undermines the legitimacy of the discipline and its claims to access funding, thus threatening the long-term survival of the discipline. Furthermore, the absence of researchers in the public sphere paves the way to a widespread political appropriation of the past that underpins contemporary nationalist or regionalist agendas. Similarly, the past is consciously and subconsciously used to naturalize inequalities and oppressions reproducing contemporary ideologies of class, gender, or individualism.

\section{Academia and the role of archaeologists in the Spain of the autonomous communities}

What we have termed the CBA appears to develop in political contexts of regionalist and nationalist nature in relation to the birth of the 'autonomous communities' in Spain. For several decades, the Franco dictatorship (I939-75) underscored the idea of Spanish national identity over the regional identities. This came to an end with the Spanish Constitution of 1978, which granted a certain degree of self-government and autonomy to the Spanish regions. As a reaction to the prior centralism, the regions tried to underpin their legitimacy through the magnification of their past and the underscoring of their differential historical and cultural traits. Northern regions like Galicia and Asturias have grounded their political discourses on the pre-Roman 
peoples, who are opposed to the 'Other' - the Roman Empire in the past, implicitly Spain in the present (Marín et al., 20I2).

Astorga is part of the Leonese Region. This territory was not granted autonomy in I978 and was integrated with Castilla y León, whose capital was placed in Valladolid. Since the I990s onwards, the perception that León was increasingly being subordinated to Valladolid gained social and political support (Díez Llamas, I997: I23-24). This feeling provided the breeding ground for the development of the Leonesist movement, organized around the regionalist UPL political party. Leonesist agents sought to legitimize their claims for the autonomy of the Leonese Region through association with pre-Roman identities. Thus, the Astur identity was wielded to counter the centralist discourse deployed from Valladolid that emphasized the shared Roman and medieval past of all the areas comprised by the 'autonomous community'.

In Astorga, the rise of the UPL in the local political arena coincided with the appearance of the Astures in the public sphere as a legitimate reference to be adopted by people as an alternative to the prevailing Roman identity. The process has repercussions not only at the discursive level of identity politics, but also conditions local cultural policies along with heritage and archaeological management. In fact, the participation of the UPL in the local government led to a redefining of the hitherto exclusive heritagization of the Roman past. In this context, the idea to excavate La Mesa Iron Age hillfort (in Castrillo de los Polvazares, municipality of Astorga) emerged. The project was included as one of the conditions that the UPL required the Partido Socialista Obrero Español (PSOE) to support their candidacy for mayor of the city council (Almanza, 2006).

The city council allotted the excavation to a private company before even posing research questions or designing a research master plan for the project. Thus, despite prior studies ascribing a Roman chronology to the hillfort (Orejas, I996), the Leonesist group asserted - before any archaeological intervention - that it was an Astur site. What is more, the project already envisaged 'the creation of a centre for the interpretation of the Astur culture' (Almanza, 2005). In 2006, the Deputy Mayor Enrique Soto affirmed that:

the centre will serve to better know our roots and how the Astures world, the hillforts and their inhabitants, were gradually incorporated in the Roman world, without any replacement of one population by another [...] the Astures maintained the customs they could preserve, and that continuity reaches our days. (Almanza, 2006)

Therefore, defining traits of the CBA like the latent Astur identity, common sense, presentism, and lack of temporal depth played a fundamental role in defining local cultural policies. In turn, this situation has had an impact in the role of archaeology as a discipline and of archaeologists as professionals. Archaeology, in this context, becomes a practice bounded to political agendas while archaeologists are considered mere technicians or hand workers executing a pre-defined plot. To make matters worse, not a single publication has been made six years after the start of the excavation.

\section{Conclusion}

Holtorf (2005) considers archaeology to be a knowledge field focusing on the study of the present through the analysis of contemporary metaphors recreating the past. 
In our view, 'public' archaeology should be situated as a mediator between both extremes mentioned by Holtorf. Our work does not attempt to 'unveil' the supposed inaccuracies of the re-enactment, nor considers it a mere 'tourism phenomenon' (cf. Rojas Rabaneda, 20II). The case study leads us to consider the CBA as a useful concept to address the complex interplay of issues of identity, politics, metaphors, and representations of the past, and the uses different actors make of heritage. It enables us to reveal how apparently neutral discourses and practices work to naturalize and reproduce contemporary ideologies. The CBA underpins certain political agendas with clear consequences for heritage management and the social perception of archaeology and archaeologists.

In sum, the CBA can be defined as a set of body technologies (Foucault, I977) and material culture, along with discourses and practices deployed during the re-enactment. The assemblage is not constructed or imposed by a single agency. Rather, it should be conceived as a distillation process, in which tiny and gradual additions are made year after year, through a process of imitation and repetition among local participants, foreign individuals, or media representations broadly. Academic knowledge and representations are largely left out of the picture. With this in mind, what can we learn from our deconstruction of the CBA?

\section{Archaeologists need to engage the public}

Historical re-enactments provide the ideal terrain for archaeologists to recover their contact with the public. They should actively participate in these events, avoiding the adoption of paternalist stances that presuppose the ignorance of the public. The public which is always multiple, reflective, heterogeneous, and increasingly multicultural, but this is generally overlooked in Spain.

\section{Assessment criteria of academic archaeology needs to change}

A shift in the assessment criteria of archaeological research is necessary in Spain. State evaluation agencies foster an idea of academic excellence derived from the 'hard sciences' - high impact publishing, patents, international projects, access of private external funding, and so on. This stance overlooks aspects of outreach and public knowledge transfer that are fundamental for our social legitimization. Our research shows how archaeology as a practice and discipline is socially constructed and negotiated. The absence of academic archaeologists in the public sphere paves the way for different actors to utilize heritage and archaeology to achieve their objectives: political, economic, and so on. That is why we deem crucial that academic assessment criteria include knowledge transfer, outreach, and public involvement. We could go beyond and consider the creation of two specialized academic archaeological pathways: one focusing in knowledge production, the other in knowledge transfer.

\section{A greater compromise with the politics of difference is needed}

That re-enactments and other public performances of the past are preferred sites for the negotiation of identity politics with pragmatic consequences. In other words, this means understanding the political agency of archaeology. In this context, limiting academic action to the adoption of a critical stance that denounces inaccuracies or political appropriations is a self-defeating strategy that furthers the gap with the 
public and has no transformative power. One of our tasks as active participants in these events should be to shift from identity to difference. That is, instead of talking about ethnicity or nation, which refers back to identity logics of easy political appropriation, we should bring to the fore overlooked issues of gender or class. Archaeology should strive to simplify the complexity of the past without falling into oppressive essentialisms.

The CBA and other similar emergent processes are 'in the making' throughout Europe. The tone of the politics, economics, and social subjects arising from them will depend in part on the degree of involvement of archaeologists in their construction. Similarly, they will also determine the future of archaeology as a discipline and a social knowledge practice. Therefore, archaeologists must go beyond our traditional disciplinary boundaries and engage the public to ensure our function as critical agents in contemporary societies.

\section{Notes}

I The Spanish 'autonomous communities' are firstlevel political and administrative entities established in the Spanish Constitution of 1978 . These institutions present a variable but normally high degree of self-governance, being responsible for the administration of Culture, Education, Heritage preservation, Spatial Planning, Social Services, Health Care, and Policing in some cases.

2 According to the classical sources and the Roman epigraphic record, the Astures were an ethnic group made up of different tribes or sub-ethnic groups such as the Ambactos, the Zoelas, or the Gigurros, among others.

3 The Cantabrian Wars (29-I9 BC) were the last episode in the conquest of Hispania by the Rome. They took place in what today are the Spanish provinces of León, Cantabria, and Asturias.

4 Data provided by the tourism office of Astorga.

5 Our research revealed that Celtiberia and Red Española de Historia y Arqueología (REHA) were among the most relevant sites used by participants. See < http://www.celtiberia.net/> and <http://www. historiayarqueologia.com/>

6 The 'Osborne bull' is regarded by many Spanish and foreigners as the unofficial national symbol of Spain. The iconic connection between Spain and the Roman is a blatant case of presentism: it condenses the two hegemonic identities into one symbol. This dominant 'ideal type' is opposed by the idealized subaltern indigenous warrior.

7 Galicia is, along with Basque Country and Catalonia, a pioneering region in the creation of national identities within the Spanish State. Together with language, archaeology has been crucial in the creation of the 'myths of origin' of the nation (Díaz-Andreu, I995; Ruiz Zapatero, 2006). The appropriation of the folkloric and popular imagery establishes links between the Iron Age mythology and the vernacular Galician society. The meigas are witches in the popular mythology of north-west Spain, while the queimada is a warm liquor consumed after the celebration of a ritual which has become a cultural icon and the perfect example of the invention of tradition, as its creation dates back to the I950s (González Reboredo, 200I: 229-30).

8 Significantly, this character does not appear in the classic sources. The first mention to it comes from Carvallo (I695).

9 Structuralist scholars in the Social Sciences use the emic/etic opposition. While the emic approach focuses in how local people think, the scientistoriented etic approach highlights the interpretations and categorizations of the external observer.

\section{Bibliography}

Agencia Nacional de Evaluación de la Calidad y Acreditación [ANECA]. n.d. ANECA para profesores. [accessed I5 February 20I4]. Available at: <http://www.aneca.es/ANECA-para/Profesores>

Almanza, M. 2005. Recuperar el castro de La Mesa de Castrillo costará 280.000 euros. Diario de León, I9 August. Almanza, M. 2006. La musealización del castro recibe una aportación de 57.000 euros. Diario de León, 2I January. Andrews, C. 20Io. Community Uses of Maritime Heritage in Bermuda: A Heritage Ethnography with Museum Implications. PhD thesis, University of Cambridge. [accessed I5 June 20I2]. Available at: <https://www. repository.cam.ac.uk/handle/I8Io/236I88> 
Appleby, G. 2005. Crossing the Rubicon: Fact or Fiction in Roman Re-enactment. Public Archaeology, 4(4): $257-65$.

Ascherson, N. 2000. Editorial. Public Archaeology, I(I):I-4.

Associacion Espanola de Fiestas y Recreaciones Historicas [AEFRH]. n.d. Bienvenida. [accessed I4 February 20I4]. Available at: <http://www.fiestashistoricas.es/>

Astures y Romanos, n.d. a. Inicio [accessed I5 February 20I4]. Available at: <http://www.asturesyromanos.com> Astures y Romanos, n.d. b. Guigurros [accessed I5 February 20I4]. Available at: <http://www.asturesyromanos. com/guigurros>

Barbero, A. \& Vigil, M. 1978. La formación del feudalismo en la Península Ibérica. Barcelona: Crítica.

Bauman, R. \& Sawin, P. I99I. The Politics of Participation in Folklife Festivals. In: I. Karp \& S. D. Lavine, eds. Exhibiting Cultures: The Poetics and Politics of Museum Display. Washington: Smithsonian Institution Press, pp. 288-3I4.

Benjamin, W. I999. Illuminations. London: Pimlico.

Burillo, F. 2005. Segeda (Mara - Belmonte de Gracián). La ciudad celtibérica que cambió el calendario. Zaragoza: Fundación Segeda.

Busquets, S. 2009. Tarraco Viva: cómo disfrutar del Imperio Romano en pleno siglo XXI. Clío: Revista de Historia, 91: 56-63.

Caro Baroja, J. 2003. Los pueblos de España, 2. Madrid: Alianza.

Carvallo, L.A. I695. Antigüedades y cosas memorables del Principado de Asturias. Madrid: Imprenta de Julián de Paredes.

Collier, S. J. \& Ong, A. 2005. Global Assemblages, Anthropological Problems. In: A. Ong \& S. J. Collier, eds. Global Assemblages: Technology, Politics, and Ethics as Anthropological Problems. Malden: Blackwell, pp. 3-2I.

Collis, J. R. 2003. The Celts. Origins, Myths and Inventions. Stroud: Tempus.

Crang, M. I996: Magic Kingdom or a Quixotic Quest for Authenticity? Annals of Tourism Research, 23(2): 4I5-3I.

Deleuze, G. 1988. Foucault. Minneapolis: University of Minnesota Press.

Deleuze, G. \& Guattari, F. 1987. A Thousand Plateaus: Capitalism and Schizophrenia. Minneapolis: University of Minnesota Press.

Díaz-Andreu, M. 1995. Archaeology and Nationalism in Spain. In: P. L. Kohl \& C. Fawcett, eds. Nationalism, Politics, and the Practice of Archaeology. Cambridge: Cambridge University Press, pp. 39-56.

Díaz Santana, B. 2002. Los celtas en Galicia: arqueología y política en la creación de la identidad gallega. Noia: Tosoxoutos.

Díez Llamas, D. 1997. El ideario leonesista. Tierras de León, 36(I02): I2I-28.

Foucault, M. 1977. Discipline and Punish. The Birth of the Prision. New York: Pantheon Books.

Geary, P. \& Contreni, J. J. 1995. Phantoms of Remembrance: Memory and Oblivion at the End of the First Millennium. History: Reviews of New Books, 24(I): 29-30.

González Marcén, P., Montón, S., \& Picazo, M. 2008. Towards an Archaeology of Maintenance Activities. In: S. Montón \& M. Sánchez Romero, eds. Engendering Social Dynamics: The Archaeology of Maintenance Activities. Oxford: Archaeopress, BAR International Series I862, pp. $3^{-8 .}$

González Reboredo, X. M. 200I. A construción de referentes de identidade etno-nacional. Algunhas mostras sobre Galicia. In: X. M. González Reboredo, ed. Etnicidade e Nacionalismo. Simposio Internacional de Antropoloxía. Santiago de Compostela: Consello da Cultura Gallega, pp. 20I-47.

González Ruibal, A. 20Ir. The Politics of Identity: Ethnicity and the Economy of Power in Iron Age Northern Iberia. In: G. Cifani \& S. Stoddart, eds. Landscape, Ethnicity and Identity in the Archaic Mediterranean Area. Oxford: Oxbow Books, pp. 245-66.

Haraway, D. J. 1989. Primate Visions. New York: Routledge.

Harvey, D. 2008. The History of Heritage. In: P. Howard \& B. J. Graham, eds. The Ashgate Research Companion to Heritage and Identity. Aldershot: Ashgate, pp. I9-36.

Hernando, A. 2005. ¿Por qué la Historia no ha valorado las actividades de mantenimiento? In: P. González Marcén, S. Montón, \& M. Picazo, eds. Dones i activitats de manteniment en temps de canvi. Barcelona: Universitat Autònoma de Barcelona, pp. II5-33. 
Hill, J. D. 1989. Re-thinking the Iron Age. Scottish Archaeological Review, 6: 16-24.

Hobsbawn, E. J. \& Ranger, T. O. I992. The Invention of Tradition. Cambridge: Cambridge University Press.

Holtorf, C. 2005. From Stonehenge to Las Vegas. Archaeology as Popular Culture. Walnut Creek: Altamira Press.

Holtorf, C. 2006. The Monumental Past. Toronto: University of Toronto Press.

James, S. 1999. The Atlantic Celts. Ancient People or Modern Invention? London: British Museum Press.

Jimeno, A. 2000. Numancia: pasado vivido, pasado sentido. Trabajos de Prehistoria, 57(2): I75-94.

King, N. \& Horrocks, C. 2010. Interviews in Qualitative Research. London: Sage.

Kristiansen, K. I996. European Origins - 'civilisation' and 'barbarism'. In: P. Graves-Brown, S. Jones, \& C. Gamble, eds. Cultural Identity and Archaeology. The Construction of European Communities. London: Routledge, pp. I38-44.

Latour, B. 2005. Reassembling the Social. An Introduction to Actor-Network-Theory. Oxford and New York: Oxford University Press.

Law, J. 2004. After Method: Mess in Social Science Research. London: Routledge.

Lorrio, A. 20I0. Los signa eqvitum celtibéricos: origen y distribución. Palaeohispanica, I0: 427-46.

Lowenthal, D. 1996. Possessed by the Past: The Heritage Industry and the Spoils of History. New York: Free Press.

Mañanes, T. I983. Astorga romana y su entorno: estudio arqueológico. Valladolid: Universidad de Valladolid.

Marín, C. 2005. Astures y asturianos. Historiografía de la Edad del Hierro en Asturias. Noia: Toxosoutos.

Marín, C. 20Ir. De nómadas a castreños. Arqueología del primer milenio antes de la era en el sector centrooccidental cantábrico. PhD thesis, University Complutense of Madrid [accessed I5 June 20I2]. Available at: $<$ http://eprints.ucm.es/I4435/>

Marín, C. \& González Álvarez, D. zorı. La romanización del Occidente Cantábrico: de la violencia física a la violencia simbólica, Férvedes, 7: 197-206.

Marín, C., González Álvarez, D., \& Alonso González, P. 20I2. Building Nations in the XXI Century. Celticism, Nationalism and Archaeology in Northern Spain: The Case of Asturias and León. Archaeological Review from Cambridge, 27(2): II-3I.

Merriman, N. ed. 2004. Public Archaeology. London: Routledge.

Meskell, L. 2005. Archaeological Ethnography: Conversations around Kruger National Park. Archaeologies: Journal of the World Archaeological Congress, I(I): 8I-Io0.

Mignolo, W. D. 2007. Introduction. Cultural Studies, 2I(2-3): I55-67.

Moser, S. 200I. Archaeological Representation. The Visual Conventions for Constructing Knowledge about the Past. In: I. Hodder, ed. Archaeological Theory Today. Cambridge: Polity Press, pp. 262-83.

Orejas, A. I996. Estructura social y territorio: el impacto romano en la cuenca noroccidental del Duero. Madrid: CSIC.

Pena Castro, M. J. 2004. El negocio de la historia en la Feria Medieval de Noia. Sociológica. Revista de pensamiento social, 5: 8I-I00.

Peralta, E. 2009. Las Guerras Cántabras. In: M. Almagro Gorbea, ed. Historia Militar de España. Prehistoria y Antigüedad. Madrid: Laberinto, pp. 247-65.

Protevi, J. 2006. Deleuze, Guattari and Emergence. Paragraph, 29(2): 19-39.

Ranilla, M. \& Grau, L. 20Ir. Musealización de los sótanos arqueológicos de Asturica Augusta (Astorga, León). Astórica, 30: 283-99.

Rojas Rabaneda, A. 20II. Herramientas y estrategias de difusión del Patrimonio Histórico: los eventos de recreación histórica en Cataluña. E-rph: Revista electrónica de Patrimonio Histórico [online] 9 December $20 \mathrm{II}$ [accessed I5 June 20I2]. Available at: <http://www.revistadepatrimonio.es/descarga.php?nombre_documento= revistas/numerog/difusion/estudios/pdf/difusion-estudios.pdf $>$

Ruiz Zapatero, G. 2005. Soria, 'Keltiberoi' — 2004: ¡la historia a la calle!. Complutum, I6: 279-86.

Ruiz Zapatero, G. 2006. The Celts in Spain. From Archaeology to Modern Identities. In: S. Rieckhoff, ed. Celtes et Gaulois, l'Archéologie face à l'Histoire, I: Celtes et Gaulois dans l'histoire, l'historiographie et l'idéologie moderne. Actes de la table ronde de Leipzig, I6-I7 juin 2005. Glux-en-Glenne: Bibracte, Centre archeologique européen, pp. 197-218.

Ruiz Zapatero, G. 20Io. Roma conquistó la Galia ... y Astérix y Obélix conquistaron el mundo. Desenmarañando a los celtas. In: M. C. Cardete, ed. La Antigüedad y sus Mitos. Narrativas históricas irreverentes. Madrid: Siglo XXI, pp. 97-II4. 
Salinas, M. I998. La guerra de los cántabros y astures, la etnografía de España y la propaganda de Augusto. In: M. J. Hidalgo, D. Pérez, \& M. Gervás, eds. 'Romanización' y 'reconquista' en la Península Ibérica: nuevas perspectivas. Salamanca: Ediciones Universidad de Salamanca, pp. I55-70.

Sánchez-Palencia, F. J. \& Fernández-Posse, M. D. I986-87. Vivienda y urbanismo en la Asturia interior: La Corona de Corporales. Zephyrus, 39-40: 375-86.

Schadla-Hall, T. I999. Editorial: Public Archaeology. European Journal of Archaeology, 2(2): I47-58.

Schulten, A. 1943. Los cántabros y astures y su guerra con Roma. Madrid: Espasa-Calpe.

Smith, L. 2006. Uses of Heritage. London; New York: Routledge.

Smith, L. T. 2005. Decolonizing Methodologies: Research and Indigenous Peoples. London: Zed Books.

Wertsch, J. V. 2002. Voices of Collective Remembering. Cambridge: Cambridge University Press.

Zerubavel, E. 2003. Time Maps: Collective Memory and the Social Shape of the Past. Chicago: University of Chicago Press.

\section{Notes on contributors}

David González Álvarez is a PhD candidate in the Department of Prehistory at the University Complutense of Madrid. His research focuses on Iron Age settlement patterns in the Western Cantabrian Mountains of Spain from a landscape archaeology perspective.

Corresponence to: David González Álvarez. Email: davidgon@ucm.es

Pablo Alonso González holds a PhD in History (University of León) and is currently a PhD candidate in Archaeology (University of Cambridge). He specializes in heritage studies in Spain and Latin America, and has published several books and papers in international editorials and journals. 